\title{
A POTENT FUEL? FAITH IDENTITY AND DEVELOPMENT IMPACT IN WORLD VISION COMMUNITY PROGRAMMING
}

\author{
MICHAEL JENNINGS ${ }^{1 *}$ (iD, MATTHEW CLARKE ${ }^{2}$, SIMON FEENY $^{3}$ iD, \\ GILL WESTHORP $^{4}$ and CARA DONOHUE ${ }^{3}$ \\ ${ }^{1}$ SOAS University of London, London, UK \\ ${ }^{2}$ Deakin University, Melbourne, VIC, Australia \\ ${ }^{3}$ RMIT University, Melbourne, VIC, Australia \\ ${ }^{4}$ Charles Darwin University, Casuarina, NT, Australia
}

\begin{abstract}
This paper explores the role of faith identity on impact in development by looking at the programming of a major international faith-based development organisation (FBDO). It argues that faith identity rests not only in the internal projected identity of the FBDO but also on perceptions of that identity in the community, highlighting the role context plays in the formulation of faith identity and its impact. Secondly, the paper argues that FBDOs possess not only a faith identity but also a development one and that it is the interplay between both that allows for the creation of engagement and trust in interventions. (C) 2020 The Authors. Journal of International Development published by John Wiley \& Sons Ltd
\end{abstract}

Keywords: FBOs; religion and development; L; World Vision; faith identity

Since the 1990s, there has been a growing focus on the role of religion in development. This has been fed by a growing interest in 'local' and non-traditional actors in development, of which religious-linked organisations play a major role. It has also reffected a recognition of the important role of culture and non-economic forces in shaping development (Clarke \& Jennings, 2008, pp. 1-4; Pearson \& Tomalin, 2008, pp. 46-47; Tomalin, 2013, pp. 1-3). Much of this literature presents religion as a new social actor, having undergone an internal shift to a more outward-looking form (Casanova, 1994; Thomas, 2005). However, religion and faith have always been important in the lives and communities of the vast majority of the peoples of the global South. It was the institutions

*Correspondence to: Michael Jennings, SOAS University of London, Thornhaugh Street Russell Square, London WC1H 0XG, UK.

E-mail:mj10@soas.ac.uk

(C) 2020 The Authors. Journal of International Development published by John Wiley \& Sons Ltd

This is an open access article under the terms of the Creative Commons Attribution-NonCommercial-NoDerivs License, which permits use and distribution in any medium, provided the original work is properly cited, the use is non-commercial and no modifications or adaptations are made. 
and policymakers of the global North who were slow in recognising this. Rather than resurgence, we should perhaps look to the 'resilience' of religion (Ter Haar \& Ellis, 2006, p. 351) and ask whether 'religious and spiritual resources produce a type of knowledge that is, or could be, relevant to development' (Ter Haar \& Ellis, 2006, p. 353). Despite coming late to the game, donors and international organisations have sought to understand what this knowledge and contribution to development might be. What is it that faith-based actors do differently to their secular counterparts: better, more problematically and just different (Tomalin, 2012)? And what is the role of faith identity in that difference?

As Rick James (2011) notes, 'faith provides more than a mere institutional vehicle: it provides a spiritual fuel for development' (p. 113). But how does that fuel differ from that of other secular development actors? Does it turbocharge the impact of faith-based development organisations (FBDOs), allowing them to achieve different, perhaps better, results than other non-faith actors? Does it create particularly sticky forms of community trust (Jennings, 2013) and thereby a platform for broad-based and deep engagement? Or is it a flammable energy, providing fuel for local tensions and potential conflicts, diving societies along faith lines or in other ways?

This paper explores how the faith identity of a global FBDO impacts on its work with communities, in particular in its ability to establish common ground and generate community participation. It challenges two understandings of religion in development. Firstly, it argues that faith identity is not just how an organisation defines itself-internally generated identity. It is also about how that organisation is perceived by othersexternally created identity. Understandings of the role of the impact of faith identity on development must account for both types. Secondly, it calls for bringing back 'development' into the analysis of FBDOs. Understanding the FBDO through a faith-only prism risks misunderstanding the ways in which faith and development values combine to generate a particular impact. 'Development', too, is more than just an institutional vehicle: it is a site of identity in itself and space for physical manifestation of values and social action aspirations.

\section{FAITH IDENTITY AND DEVELOPMENT}

As Ware, Ware, and Clark (2016) point out, 'the literature reveals complex and seemingly contradictory findings about the ways faith or religious motivation shape both faith-based organisations (FBOs) themselves and development process' (p. 322). Some have suggested that there are particular types of activity that FBDOs are more likely to engage in, areas that might better reflect their faith values, and may offer a point of difference from secular organisations. Humanitarian activity, social service provision and child-focused development, for example, may be areas with less potential for clashes with faith teachings (Vander Zaag, 2013). Moreover, the teachings of most world religions contain obligations for the faithful to act in these areas as a sign of their faith. However, the idea that some areas may provide easier access to faith-based approaches is more nuanced than the broad generalisations suggest: engagement in health services brings into play women's health, sexual health and programmes based around HIV, all of which create challenges for reconciling aspects of religious teaching with best practice approaches. Similarly, many FBDOs engage in issues around gender and gender-based violence, areas that some (Molyneux \& Razavi, 2006; Pearson \& Tomalin, 2008) have noted could be especially problematic for faith-based actors. In general, most FBDOs engage in very similar areas 
to secular NGOs, including in programming that may be considered more sensitive. Nor is a sense of 'duty' or a 'servant-hearted approach' (Aiken, 2010, p. 9) necessarily rooted solely in faith-based approaches. Many secular NGOs (and their staff) would share a set of drivers based on compassion and ideas around social justice, even if they are not framed in explicitly religious terms.

Another way of thinking about the way in which religion and faith make a difference in FBDOs is whether they possess particular institutional forms that shape what they do and how they do it: for example, their place within globalised networks of faith as well as within local communities. In relation to the institutional architecture, faith identity can provide an organisational rationale and motivation for development, as well as providing access to a set of resources (through globalised faith networks), and can motivate individual members of staff who share that religious worldview (Berger, 2003; Jennings, 2013). Many FBDOs have faith not only wired into their organisation (through linkages to religious organisations, membership of boards, explicit organisational missions, and through its sources of funding) but also in the commitment and vision of their staff who see their roles as supporting their faith as well as communities with which they work (Davis et al., 2011, pp. 141-43).

Finally, with a spiritual perspective embedded in their practice, FBDOs may share a worldview and way of thinking with the communities with which they engage, even if they do not share the same specific religion (Aiken, 2010; Davis et al., 2011; Jennings, 2013; Ware, Ware, \& Clarke, 2016). This can create particular avenues for building trust with and between communities. 'FBOs are more likely to be trusted', Ware et al. (2016) suggest, 'where programme implementation aligns with local religious beliefs' (p. 326): giving FBDOs not only a point of entry to communities but also a mechanism for establishing trust in the organisation and what it is doing. As Swart (2006) notes for South Africa, religious organisations command a level of public trust unmatched by any other type of social institution (p. 346). Although FBDOs may well be external actors to the community, their shared faith or acknowledgement of the 'reality' of the spiritual realm means they can often more easily gain the trust of local communities (Jennings, 2013).

A shared worldview can increase levels of trust, but it can also exacerbate social tensions in or between community groups. Communities of different faiths (or denominations within the shared faith) may fear they will be excluded or targeted for proselytization under the cover of development. Donors often share such fears and insist on the creation of artificial impermeable boundaries between 'faith' and 'development' activities, reinforcing the idea that both operate separately and independently (Aiken, 2010, James, 2011; Hovland, 2008). As Tomalin (2020) notes, donors have taken a 'selective and normative' approach to engaging with religion in development. Faith identities may also pull practice in unhelpful directions where religious teachings clash with best practice or human rights approaches. Faith-based actors have provided the majority of care for those living with and affected by HIV and have used faith-based teaching to encourage behavioural change. At the same time, many have been accused of promoting stigma in their response to HIV, for example, or harmful messaging in prevention strategies (Garner, 2000; Green, 2003). Gender is another potential clash point. Can organisations with troubling teaching on gender equality and equity be trusted to speak out on gender-based issues (Molyneux \& Razavi, 2006, p. 18)? Could this silence 'women's voices' and slow 'progress towards gender equality' (Pearson \& Tomalin, 2008, p. 65)?

Carole Rakodi has highlighted four areas where religious organisations and FBOs might make a distinctive contribution: firstly, through their 'inputs' (the activities they design, 
their theory of change models and their sources of funding); secondly, their particular 'ways of operating' (including how religion is integrated into their action); thirdly, their 'outcomes'; and fourthly, their 'impact' (Rakodi, 2012, p. 646). Useful as this framework is, it presents faith as the sole distinctive marker of FBDOs - a tendency reinforced by a tradition in the literature of writing about FBOs rather than FBDOs. Secondly, it sees faith identity as something created by and vested in the institution itself, rather than something that is also seen by others: donors, governments and especially communities.

Our paper contests analysis that isolates and reifies the faith aspect of FBDOs above other parts. We suggest that what gives potency to the claims for faith are the ways that faith identity is expressed through development. Faith-based actors do not enter as either faith or development actors but faith-based development ones. What allows FBDOs to have an impact is not necessarily the way in which faith works in development but the way faith and development interact: faith identity feeds development interventions, which in turn feed back into the perceived faith identity.

We also argue that analysis must not look only at internally generated faith identity but understand how that identity is seen and shaped by the communities themselves, putting the context in which these relationships occur at the centre of analysis. FBDOs do not operate as abstracted organisations but through activity in a specific space. De Cordier (2009, 679-80) identifies a number of contextual factors that can determine the value added by faith, including the extent of local religious tensions and the place of religious leaders in local communities and the extent to which religion is the key 'social fault line'. What an FBDO believes its faith identity to be is not necessarily how communities see it in the crucible of the development intervention context. Moreover, the extent to which communities buy into that identity and engage with it (creating the opportunity for it to have an impact) is not just a dialogue focused on faith but on the interplay between faith and development. As a result, the same FBDO may look quite different from one context to the next and from one level of operation to the other.

In other words, the 'distinctive contribution' and impact of faith identity in development is a mutual construction of projected (internal) and perceived (external) faith identity and the result of a complex interaction between faith identity and development identity. FBOs are not only faith organisations and not only development ones. FBDOs have both, even if they are not necessarily constructed in such binary ways. But it is this combination of faith and development that builds or lessens trust, encourages or discourages participation and engagement and can create or limit impact as a result. Faith identity impact is complicated, non-linear and reflective of this double identity.

\section{METHODOLOGY}

To explore the role of faith identity in development, we looked at the working of a global FBDO, World Vision (WV), across area development programmes (ADPs) in five different countries-Banja, Ethiopia; Diakhao, Senegal; El Salvador, Peru; Samtskhe-Javakheti, Georgia; and Navithanveli, Sri Lanka-reflecting differing faith communities and contexts. WV has extensive global reach. In 2014, it was working in 95 countries, delivering ADPs (which are run by national WV offices, supported financially by WV Support Offices) in 1614 communities that reach an estimated 120 million children. The aim of ADPs is to improve the well-being of children, especially the most vulnerable. 
Primary data were gathered from sets of interviews with stakeholders in each ADP site: adult community members, adolescents living in the community, faith and community leaders, partner organisations working with WV (drawn from governmental and non-governmental sectors) and WV ADP staff (Table 1). Participants were selected by the academic researchers, drawn from lists provided by the programme staff. Community members were selected randomly while trying to account for a number of representative characteristics such as varying levels of participation with WV, varying sponsorship statuses, different vulnerable groups, a range of locations, ethnic and religious diversity, similar numbers of men and women, and varying ages and representation across partner organisations. In addition, snowball sampling was used for a small number of interviewees in each subgroup, by asking interviewees to recommend three to four other people they thought would be willing to complete an interview. Where the sample was not adequately representative, interviewees were asked to suggest people who met missing specific criteria.

The interviews were designed by the research team, translated into local languages and tested with the research assistants before being rolled out across each ADP. Local research teams were used in each country to carry out the data collection under the supervision of one of the academic research team leads.

Informed consent was sought from all participants, information about the research having been provided. The voluntary nature of participation was emphasised, and all were informed that there would be no adverse or beneficial consequences to their relationship with WV whether they participated or not, nor for any responses given. No research participants, including specific staff and partners of WV, are identified in the project documentation, research results or publications. For children and persons with a disability, consent was gained from their parent or guardian, and assent was gained from the child/person with a disability either in writing or verbally. Because the research was conducted in countries where working with children checks are not established, all researchers were required to meet WV's protocols for working with children.

\section{FINDINGS}

Three key findings emerge from this research. Firstly, the research showed that WV's Christian (faith) foundation is indeed an important aspect of its identity. It allows the NGO to work in particular ways, especially (but not only) in ways that explicitly recognise and acknowledge faith and spiritual worldviews that are important to communities in the areas in which they work. It also helps them work with particular groups (especially faith

Table $1 . \quad$ Interviewees by country and subgroup

\begin{tabular}{lllllll}
\hline Subgroup & Ethiopia & Georgia & Peru & Senegal & Sri Lanka & Total \\
\hline Adult community members & 19 & 25 & 25 & 26 & 22 & 117 \\
Adolescents (12-17 years) & 22 & 19 & 20 & 22 & 19 & 102 \\
Faith and community leaders & 22 & 10 & 10 & 19 & 9 & 70 \\
Partners & 11 & 11 & 10 & 9 & 8 & 49 \\
ADP staff & 4 & 6 & 6 & 9 & 6 & 32 \\
Total interviewees & 78 & 71 & 71 & 85 & 64 & 370 \\
Total participants & 78 & 71 & 71 & 85 & 64 & 370 \\
\hline
\end{tabular}

ADP, area development programme. 
leaders). As a result, it helps build trust in its programmes and its intentions within programme sites and increase engagement in those activities as a result.

Secondly, this identity is created in the ADP sites through both its own internally defined identity and externally reconstructed perceptions of that identity. WV presents itself as an overtly Christian organisation at international, national and local levels, but the evidence showed that WV's faith identity as recognised in communities was understood through the prism of the specific cultural, social, political, economic and religious mix of each site, and this in turn affected how communities engaged (or failed to engage) with the FBDO's programming. While WV's faith identity was recognised by communities, the precise manifestation of this identity was not the same across all research sites, nor necessarily reflective of official WV understandings of its Christian mission and values at international (or even national) levels. These dynamics reflected the faith landscape of the individual sites: the extent to which communities were predominantly single or multifaith; the extent to which different Christian denominations were competing with each other for faith adherents; and whether there had been recent experiences of tensions or conflicts, which had played out along religious, ethnic or national lines.

Third, the research suggested that WV was able to build common ground based on a sense of shared values but that this was the result of the intertwining of its faith and development-oriented values. This draws our attention to the importance of seeing WV as an FBDO, rather than just an FBO. In other words, faith identity can indeed be a fulcrum around which a sense of shared values and objectives can be created, but it is the interplay between those faith values and 'development' ones that are critical to that outcome.

\subsection{Internal (projected) faith identity}

World Vision is a self-professed Christian-based development organisation. It describes itself as a non-denominational Christian organisation acting as 'an international partnership of Christians whose mission is to follow our Lord and Saviour Jesus Christ in working with the poor and oppressed to promote human transformation, seek justice and bear witness to the good news of the Kingdom of God' (World Vision, 2020a). As part of its Global Christian Commitment strategy, WV has six key objectives for linking its development and relief activity to that Christian witness: (1) 'Reinforce WV's Christian identity, foundations and witness'; (2) to 'Equip staff for Christ-centred life and work'; (3) 'Engage supporters and Churches'; (4) 'Ensure children and youth have opportunities to experience love of God and their neighbours'; (5) 'Encourage inter-faith cooperation'; and (6) 'Contribute to a global movement of prayer'. WV's Christian identity is, then, overt, intended to guide all that it does and the way that it does it, and applied across its entire institutional architecture. It presents itself as a Christian organisation and expects to be seen as such in the communities with whom it works.

Although all aspects of its work are framed within this Christian faith identity, WV has a number of specifically faith-linked programmes, including Channels of Hope, Celebrating Families and two former initiatives, the Hope Initiative and the Christian Witness Initiative. The focus on child well-being as the key strategic objective of WV also includes an explicit spiritual dimension, with enabling children to 'experience the love of God and their neighbour', one of the organisation's four key child well-being aspirations (World Vision, 2013). 
As with studies of other FBDOs (Aiken, 2010; Berger, 2003; Davis et al., 2011; James, 2011), our research found that WV staff had a clear understanding of WV's official faith identity and that this acted as motivation and guide for their understanding of what they were doing and why. In almost all sites, WV staff defined their work and the principles underlying their organisation in explicitly religious, and mostly specifically Christian, ways. Even in Diakhao, Senegal, where WV staff consisted of both Christians and Muslims, ${ }^{1}$ the internal identity was one centred around a clear set of Christian teachings and values. One staff member described how these religious values played into programming and building community engagement:

We can clearly explain to communities what it is when we say we are Christians ... [It] does not mean that ... we'll just evangelized people or others. [It is] ... the values embodied [in] Christ, the value of justice values to help the poorest to be there for children, and all these are aspects we try to perpetuate through our actions. (Senegal I24)

We ... talk about God because ... it is the motivation, the interest of the project ... I tell the parents that they have to vaccinate their children during the first five years not only because it is a development check-up but ... because God cares about the life of your child, the life of your child is sacred as well as yours.... It is not an NGO telling you this but God telling it to you; therefore I am not talking about religion, I am talking about health, which is involving the whole human being ... the child has to study and get good grades because that matters to God too, he should do it well .... then that way I am not proselytizing, pure religion, were just talking about integral development. The institution is all about that, that God is involved in everything. (Peru Staff 07)

Similarly, in Peru, El Salvador, ADP office staff made an explicit link between their activities and religious teaching and values. This (long) quote captured the approach of the ADP office to its development activities: This quote raises some interesting questions about the potential consequences of conflating the word of the development worker with that of 'God'. It can encourage action or behaviour change (to be a 'good' Christian or Muslim, etc.). But if the advice is against best practice or carries the potential for harm - as seen in the early responses of many religious organisations to HIV - then the added spiritual authority of such pronouncements could be a cause for concern.

A Catholic staff member in the Peru site noted their own comfort in working for what was regarded locally as a Protestant-based organisation and the importance of demonstrating faith identity: 'I have never felt any bias because I am a Catholic. I identify [World Vision] as a Christian organisation. When we introduce ourselves, we are also a Christian organisation' (Peru Staff 04). Programmes that explicitly linked child well-being to development activities also reinforced the religious identity of WV. For example, Channels of Hope worked with local churches to improve child protection from an explicitly 'theological point of view' (Peru Staff 5).

Staff respondents in most sites see their work as directly linked to their own religious faith and values. Although it did not emerge in the evidence, it is possible that this creates

\footnotetext{
${ }^{1}$ Unlike the other ADP study sites, WV in Senegal had a higher proportion of non-Christian (in this case Muslim)
} staff at national and district levels. 
higher levels of commitment to the activities and a sense of a higher purpose even when undertaking relatively mundane tasks (see Seemann, 2016, for example). It also indicates the way in which WV staff express their 'development' mandate: in terms that explicitly reference religious (and specifically Christian) teachings and obligations of the faithful. This internal projected faith identity of WV is critical to the identity of both organisation and of those working for it, 'integrated into organizational culture' (Aiken, 2010, p. 5) and maintained by those staff in its everyday working practices and engagement with development partners and communities.

The expression of faith identity was far more muted, however, in the Georgian Samtskhe-Javakheti (S-J) ADP, a region affected by the 2008 conflict with Russia, and containing a mix of faith and ethnic communities. ${ }^{2}$ This reflected a conscious decision by the area office to operate and identify primarily as a development organisation rather than an FBDO, believing this would better allow for the creation of shared values across and between all communities. The decision not to emphasise faith in interventions was a strategic (not a value) one, although as will be seen, this may have contributed to a failure to secure cross-community participation in activities.

\subsection{External (imposed) faith identity}

Despite its own clearly internally understood faith identity and the efforts of WV ADP staff to live that identity through its actions, the way that WV was perceived within communities and by partners in almost all cases differed from the official internal version.

In the two majority Christian sites (Banja, Ethiopia, and El Salvador, Peru), WV was perceived as an explicitly Protestant (not non-denominational) organisation. This meant that despite sharing a wider 'Christian' identity, WV's perceived particular Christian identity created points of difference, rather than of commonality and shared values, which generated some suspicions over its intentions. Although WV does not undertake conversion activity as part of its programming, such suspicions led to initial assumptions among some community members that this was its purpose. In Banja, some community members belonging to the Ethiopia Orthodox Church and Orthodox religious leaders believed that WV was using its programming to attract converts to a Protestant faith. Child sponsorship, a core feature of WV programming, was identified by them as a potential site for such activity and part of a strategy to convert children to Protestantism. One Orthodox faith leader claimed that sponsorship was a tool for evangelical activity, asserting 'those children who are sponsored were asked to follow Christian [Protestant] identity. Even though WV did not express it explicitly, it tried to convince, forced the sponsored children and their parents' (Ethiopia TR71). ${ }^{3}$ Another faith leader reported this to be a common belief: 'In some communities there is a misunderstanding that $\mathrm{WV}$ is going to expand Christianity [Protestant]' through conversion activity (Ethiopia TR70). Beneficiaries also expressed such concerns: one reported that 'at the beginning some people blamed that World Vision tried to make people Protestant' (Ethiopia TR26); another reported that people in the community had accused WV of aiming at 'expanding Protestant faith' (Ethiopia TR45). ${ }^{4} \mathrm{WV}$ staff-all of whom belonged to Protestant churches - recognised

\footnotetext{
${ }^{2}$ Including the Georgia National World Vision Office, in which Christian identity was significantly more overt and manifest in activities such as group worship, unlike in the area office.

${ }^{3}$ These numbers reflect the coding for interviews for each site.
} 
these suspicions. 'It is Christian organization [and] some people are still suspicious [of] its projects', one said. '[T]hey said World Vision is "Protestant"', suggesting this may give 'rise [to] conflict between users' (Ethiopia Staff R01).

In Peru, too, WV was seen as a Protestant organisation, not least through its use of gospel-centred language and bearing witness (discourses seen by many communities as belonging to an evangelical and Protestant tradition). Inevitably, perhaps, there were tensions with the Catholic Church, also a major player in development and social welfare work in the urban area. One Catholic staff member stated that while WV was generally well received within Catholic communities, 'I have felt more prejudice on the part of the Catholic Church’ (Peru Staff 04). Another staff member agreed:

It seems that here it is where we have more difficulties with the church Catholic church because they always see WV as an Evangelical church; Catholics already know them that way, as an Evangelical NGO, as if all of us were evangelical. (Peru Staff 07)

Complicating efforts to work across all religious communities and partners were the actions of the WV Support Office. ${ }^{5}$ The Finnish Support Office had until recently discouraged $^{6}$ working with other church-based organisations and leaders, including the Catholic Church (Peru Staff 5). The perceived unwillingness of WV to work with the Catholic Church may have appeared as further evidence that it favoured a particular faith community in its dealings, reinforcing the external perception of WV as a Protestant, rather than a non-denominational organisation. ${ }^{7}$

In the multifaith sites (Diakhao, Senegal, and Navithanveli, Sri Lanka), suspicions over WV's potential conversion activities were similarly expressed, mostly among non-Christian communities. In Diakhao, Muslim religious leaders were generally positive in their perception of WV, acknowledging a shared sense of religious values. One Imam described relationships with WV as 'only ... positive', emphasising shared values in development (Senegal I21). Another highlighted the respect WV showed to faith leaders, especially those from other religions: WV 'respect their words and deeds', and 'when they come to work, they say it well and do it well' (Senegal I28). Yet another Muslim faith leader emphasised the support for all religious communities given by WV: 'Once they arrive they help religious people and they support the religion' (Senegal I07).

Some responses, though, did reveal fears over WV. Employing metaphor, one faith leader described WV's approach as salting the sugar: 'As I had told you, they say that World Vision is misleading us', using control over resource allocation to mobilise engagement while stifling criticism of the organisation ('it is necessary to take sugar and not to criticize that which ... gives it') (Senegal $122^{8}$ ). WV staff recognised some of the suspicions within Muslim communities, saying 'some people refuse [to participate] because they are apprehensive because they simply do not understand. Besides, many

\footnotetext{
${ }^{4}$ To reiterate the point made previously - WV was not engaged in conversion activity. These were perceptions by some community members, which, as the paper shows, were later largely overturned as they engaged more with the organisation.

${ }^{5}$ Different WV offices take responsibility for supporting national and district WV programmes.

${ }^{6}$ The Finnish WV Office was restricted by the Finnish government from engagement in explicitly religious activities, though may have interpreted this rule more strictly than the law required.

${ }^{7}$ This suggests researchers should look at the architecture of large FBDOs and INGOs in thinking about their 'identity', as identity may look different across levels and stakeholders.

${ }^{8}$ The faith leader was not making this allegation against WV himself but reporting complaints and comments of some in the Muslim community.
} 
people think that there are only Christians at World Vision while there are Muslims' (Senegal I30).

The actions of sponsors living in donor countries (many of whom are Christians) had the potential to exacerbate tensions. In one instance, a sponsor sent to a Muslim child a cross (which is against the rules). A staff member explained why this was problematic:

You see this cross, it is not mine. We found it in a letter. It is part of our banned practices to avoid these evangelistic stuff. Sponsors are usually Christians, but they can sponsor a Muslim child. Maybe in their mind it's nothing to send a cross to a child, it's just to show the child what they believe. ... So when we receive the mail we check to see if there are no religious elements that can hinder or may hinder the relation[ship] with the parents of that child. So at the community level, we do everything not to offend. (Senegal I30)

While an isolated incident, it reminds us that the faith identity of an FBDO is constructed in multiple sites and by multiple actors, complicating the extent to which we can talk simply about any particular 'faith identity' of an organisation.

In Navithanveli, Sri Lanka, the legacy of conflict hampered initial efforts to establish a sense of common ground and shared values across faith communities in its work and activities. The conflict had made it much harder to engage with Sinhalese and Muslim communities in particular (SQ003). A number of Muslim respondents reported community pressure not to participate in WV activities over fears of its intentions. One adolescent said that youth had been told not to participate and forbidden from attending training sessions: 'In our village people said that the WV is a Christian organization and when we participate in their programme, they will finally change us as Christians' (ADQ004). Others saw mixed-faith activities as a potential source of threat to the religious values of Islam, and faith leaders discouraged (Muslim) community participation:

Some criticisms surfaced with regard to the Muslim women's dress and nonMuslim's dress. According to Islam Muslim women must avoid public places where there is a free mix of sexes. This is the view of the Muslim religious leaders.... When they were seen in male dominant public events men preoccupied with religion had expressed their dissatisfaction and advised them to keep their interaction with World Vision to a minimum. (ADQ007)

Efforts by the organisation to demonstrate that they were trying to support all communities were sometimes hampered by where activities took place. The use of a temple, for example, led to community concerns, as noted by a faith leader: '[The] Muslim community ... think we are teaching [our] religion since this is inside the temple .... But we do not do any such. We allow children to follow their religion' (FCL005). While religious buildings may offer an obvious place for an activity (often likely to be the largest or most convenient space in a community), they can also be divisive for those of other faiths.

Non-Christians were not always more suspicious of WV for its overt Christian identity. In Banja, Ethiopia, some members of the local Muslim community saw WV as an ally, supporting Muslim community development and helping to reduce interfaith tensions through cross-faith forums for all religious leaders (Ethiopia TR73, Ethiopia TR70 and Ethiopia TR78). Two faith leaders noted WV's role in improving tolerance between faith communities after these meetings and discussions (Ethiopia TR70 and Ethiopia TR78). There was a sense that $\mathrm{WV}$, as an external organisation and one not rooted in the dominant Orthodox tradition, was a supportive partner for Muslim leaders and communities. 
Although faith identity was significantly more muted in the S-J ADP, some suspicions about WV and its faith identity did exist. One community member reflected: 'I remember that time, when World Vision started working in our community, there were several questions, people were quite suspicious about their activities or goals, even some of them were afraid, because there were some rumours about [whether] World Vision was or wasn't [a] religious organization' (Georgia DTS01). That there was even room for doubt in the community over WV's faith identity suggests the ADP Office was indeed downplaying the organisation's faith foundations, perhaps in response to such suspicions. In another instance, a mother took her son out of an activity, claiming to have been advised to do so by a priest (who himself denied this) (Georgia DTS27). Orthodox priests reportedly tried to persuade others not to participate in the Child Sponsorship Programme too (Georgia W3).

One consequence of this reluctance to challenge cultural-religious beliefs in S-J has been a possible weakening of WV's messaging on key issues in some circumstances. One partner in WV supported activities said: 'we have to refrain ourselves from certain things, we are not able to talk openly about certain values' (Georgia NO2). Another consequence has been a markedly more intercommunity, rather than cross-community, approach to activities. As a result, it is not surprising that trust in $\mathrm{WV}$, its intentions and activities, was largely based on its development, rather than religious, identity.

\subsection{Faith and development}

That the S-J office was able to play on its 'development identity' rather than faith one highlights the importance of seeing WV (and other FBDOs) not just as an FBO but an FBDO. Across all sites with the exception of S-J in Georgia sustained contact and engagement with WV and its activities was able to dispel or mitigate some faith-related concerns. In these instances, there was a shift away from a focus on points of intra-faith difference to a growing recognition of shared values and growing trust in WV's declared intentions to be working for the good of all communities.

In Banja, Ethiopia, for example, one beneficiary described how initial beliefs that WV 'only support Protestant' groups and wanted to 'make people Protestant' had changed: 'this problem no more exists' (Ethiopia TR31). This change was also noted by a faith leader: 'Before this, the community related the projects with religion. Now the people understand that it is not for religion; it is for development [for] a better life' (Ethiopia TR76). One faith leader who had earlier referenced suspicions about the intentions of WV concluded by asserting WV 'works for all human beings equally', with 'no discrimination' between those of different faiths (Ethiopia TR70).

A result of this association with WV with development and faith objectives was not only to lessen suspicions over potential proselytising activity but to expand WV's perceived particular denominational faith identity to a more generalised Christian one. Respondents drew links between Christian teachings and values and the work that WV was doing in addressing poverty. One faith leader described WV's work as 'Christianity in action', going on to say 'Helping those who are poor, helping those who are exposed, [this] is the doctrine of Christianity' (Ethiopia TR70). 'In church we preach about hard work and development', said a community leader, 'the Bible says if you work together, you get a better thing' (Ethiopia TR82). For other organisations, it was a more explicit 'development' set of values that common ground could be built around. As one member 
of a partner organisation said, it was the 'mutual goals and values' of WV (without reference to faith or religious values) that made it an attractive partner, as well as its potential for bringing in funding in a context of 'scarcity of resources' (Ethiopia TR53).

Trust in WV in Diakhao, Senegal, was already relatively high. But even here, embedding its faith identity within 'development values' had a similarly positive effect. As one community described it: 'In fact, even if you do not share the same religion and that you share the same ideas, that it there an agreement it is something good... WV ... help[s] us' (Senegal I39). A story told by a Muslim respondent captured this. He had been provided with rice and clothes by a Catholic Abbot: 'When I returned, my father refused to take it. He said he will not eat it. He said a Muslim should not have problems and go and see an Abbot'. Yet when asked if this meant that WV's Christian identity was similarly problematic, he replied: 'No because they come, they give you what they should give you and they leave ... That's it, there is no constraint' (Senegal I44). Both institutions have a clear Christian faith identity. But WV's is associated here with social action, not an explicitly religious objective. WV can move more readily between an expression of faith, humanitarian and development values, without being irrevocably tied to one alone. As one respondent noted, it is WV's ability to provide support and resources that is critical to engagement: 'If I see someone who can help me, I'll cling to him so he could help me. This will not affect my religion' (Senegal I53).

Navithanveli, Sri Lanka, was a more difficult environment for WV to gain trust and engagement, owing to the legacy of conflict and violence. Nevertheless, as WV became linked in community minds to development programmes and interventions and less with its religious identity, participation became more acceptable to non-Christian groups. The respondent who voiced concerns over potential for evangelisation as part of participation in activities noted this shift in attitudes:

But with the awareness creation and the encouragement of WV our parents let us to go for the residential trainings organized by the WV. Now we participate even for two or three days training. ... as we participate for the trainings and the awareness programme of WV we found that they are working only towards our development [not conversion]. They teach us about all like education, health, child abuse etc.... So, they are working for development, not to make us as Christians. (ADQ004)

... when you take Christian religion and Islam religion you see some activities are different. Like that in Hindu religion also some of their approaches are different. So that is based on everyone's believes [sic] but WV will take decisions which all are able to accept... They have some honesty in it...Yes neutral. ... But, the very good thing about the organization [WV] is, they never act like, we are like this and you have to adjust to us; they are flexible and adjust toward the culture and religious practices of that area and do the good work. (AQ025r)

Another community member similarly described the way in which WV expressed its identity through action: The focus of activities - education, child protection, health and so on-were seen as good in themselves, transcending specific religious values. This created an opportunity for shifting the perception of WV as narrowly sectarian and emphasise the 'development' aspect of its identity. As the same respondent noted, 'There was religious differences in the community. Now those feelings have reduced. A feeling that we are all human has increased a bit' (AQ025r). 
Where religious tensions between differing denominations was high and WV was regarded as belonging to one tradition, such as El Salvador, Peru, 'development' discourse was a fulcrum around which common agreement could be reached. A development partner outlined how the non-faith-specific values of 'respect, responsibility and hard work' were ones that were shared by both themselves and WV (Peru 8). For another partner, it was the emphasis on child well-being: 'they help children to improve their reading comprehension' and 'it's the social assistance that they provide. Social assistance to the children' (Peru 10). For such partners and development workers, explicit reference to religious values was offputting. One respondent described how training on child rights 'failed' when it 'centred on religion' and praised one trainer who adopted a more neutral (topic-focused) approach (Peru 8).

\section{DISCUSSION AND CONCLUSIONS}

One finding from the research is the complexity of thinking about faith identity in relation to FBDOs. Large organisations especially with institutions at international, national and local levels, with support and implementing agencies, may each have different ideas about what their 'shared' identity is. External stakeholders also have an impact: official donors who may pressure the organisation to downplay its faithness (Hovland, 2008; Hershey, 2015) or private donors who may want a more explicit (or particular type) of faith identity expressed. This research in particular draws attention to the ways in which internal, projected faith identity must negotiate with external perceived identity and in the process becomes something new. Finally, we need to recognise that for FBDOs, faith identity is inextricably entwined with a development one, and it is this interaction that creates particular pathways for interventions, opportunities for impact and potential obstacles and challenges.

World Vision's faith identity allowed it to work in particular ways (especially acknowledging the place of the spiritual in development) and with particular groups (especially faith leaders) and through that build trust in its programmes and its intentions and increase community engagement in WV supported programmes. In communities where a significant proportion of the population holds religious or spiritual beliefs, FBDOs are able to frame their internal identity and values within a broader social discourse of development, religious (social) values and obligations and through that establish common ground within individual and between different, faith communities. That common ground can then be used to build engagement and support in development activities, boosting participation rates and securing community support for both the initiatives and their objectives.

However, the research also highlighted the important ways in which specific contexts shape the way and extent to which this process occurs, suggesting that thinking about a single impact and pathway for faith identity in development (one consequence of trying to think of FBDOs as organisational types rather than contextually-based and evolving entities) is unhelpful and likely to miss important dynamics.

The Christian identity of WV as a mechanism for securing engagement, participation and trust from communities cannot be seen in isolation from its development identity. WV must be seen as occupying a faith and a development space. There is a degree of artificiality in splitting identities into separate 'Christian' and 'development' components. Internally, many staff may feel that their work in the organisation reflects a spiritual calling and imperative. Externally, community worldviews may see well-being and 'development' 
as including a spiritual dimension. However, there is a sense in which both operate independently as well as in concert, reinforcing or challenging perceptions and impacting on trust. Thinking back to the question about what it is that FBDOs do differently to their secular counterparts, it is perhaps the ease with which they can move from expressing values, objectives and principles in faith to more traditionally secular development terms and the ways in which activity in each reinforces the other.

These conclusions have implications beyond the sphere of faith-based development: the same question could be asked of any organisation with a self-professed set of values. Ultimately, this is a question about the role 'values' and 'identity' play in development and how they can facilitate or impede participation and outcomes. To twist slightly Ferguson's (1994) argument, development is an anti-values machine. It professes a focus on measurable outcomes, efficiency and cost-effectiveness and masks value-based assumptions about society, change and what 'better' means. While this might be more overt when translated into political values (reflected in battles between the champions of more market-focused, neoliberal forms of development and those who push against the policies and assumptions those 'values' have led to), all development and all development organisations have identities that are important in self-understanding and in how those organisations are in turn perceived. NGOs, donors and other development actors are all value-laden and value driven, even if that specific value identity is not always as easy to categorise as it can be with the clearer demarcations of faith identities. Identity and values matter in and impact on development, whether faith, secular or somewhere in between, and whether hidden, open or (deliberately?) written out of the script.

\section{ACKNOWLEDGEMENTS}

The authors thank all community members, partners, local stakeholders and staff who generously gave their time to participate in this research. This includes staff from World Vision International, National Office and Area Development Programme Staff especially to those who provided extensive support for the fieldwork. The authors also thank the local (non-World Vision) research teams who participated in the fieldwork: Atem Consulting (Ethiopia); GeoWel Goal Oriented Research (Georgia); INEVA Consultores (Peru); PASSAsia (Sri Lanka); and Professor Sylvian Faye and his team from the Sociology Department at Cheikh Anta Diop University (Senegal). This research was funded by World Vision as part of the Child Sponsorship Research Programme, Phase 3.

\section{DATA AVAILABILITY STATEMENT}

The data that support the findings of this study are available on request from the corresponding author. The data are not publicly available due to privacy or ethical restrictions.

\section{REFERENCES}

Aiken A. 2010. Assessing the impact of faith: a methodological contribution. INTRAC Praxis Note no. 55 . 
Berger J. 2003. Voluntas: International Journal of Voluntary and Nonprofit Organizations 14(1): 15-39. http://dx.doi.org/10.1023/a:1022988804887

Casanova J. 1994. Public Religions in the Modern World. University of Chicago Press: Chicago and London.

Clarke G, Jennings M. 2008. Introduction. In Clarke G and Jennings M (eds). Development, Civils Society and Faith-Based Organisations: Bridging the Sacred and the Secular. Palgrave Macmillan: Basingstoke and New York: 1-16. https://doi.org/10.1057/9780230371262

Davis C, Jegede A, Leurs R, Sunmola A, Ukiwo U. 2011. Comparing Religious and Secular NGOs in Nigeria: Are Faith-Based Organisations Distinctive?, Working Paper 56, Religions and Development Programme, Birmingham University.

De Cordier B. 2009. The 'Humanitarian Frontline', Development and Relief, and Religion: what context, which threats and which opportunities?. Third World Quarterly 30(4): 663-684. http:// dx.doi.org/10.1080/01436590902867086

Ferguson J. 1994. The Anti-Politics Machine: 'Development', Depoliticisation, and Bureaucratic Power in Lesotho. University of Minnesota Press: London and Minneapolis.

Garner RC. 2000. Religion as a source of social change in the new South Africa. Journal of Religion in Africa 30(3): 310-343. https://doi.org/10.1163/157006600X00555

Green EC. 2003. Faith-Based Organizations: Contributions to HIV Prevention. Washington DC: USAID.

Hershey M. 2015. Understanding the effects of faith: a comparison of religious and secular HIV prevention NGOs in Kenya. Journal of International Development 28: 161-176. https://oi. org/10.1002/jid.3075

Hovland, I. 2008. Who's Afraid of Religion? Tensions between 'Mission' and 'Development' in the Norwegian Mission Society. Clarke, G \& Jennings, M, Development, Civil Society and Faith-Based Organizations: Bridging the Sacred and the Secular. London: Palgrave Macmillan: 171-186.

James R. 2011. Handle with care: engaging with faith-based organisations in development. Development in Practice 21(1): 109-117. http://dx.doi.org/10.1080/09614524.2011.530231

Jennings M. 2013. Do not turn away a poor man: faith-based organisations and development. In Clarke M (ed). Handbook of Research on Religion and Development. Edward Elgar: Cheltenham and Northampton Mass.: 359-375. https://doi.org/10.4337/9780857933577.00029

Molyneux M, Razavi S (2006) Beijing Plus 10: An Ambivalent Record on Gender Justice. NRSID Occasional Paper 15.

Pearson R, Tomalin E. 2008. Intelligent design? A gender-sensitive interrogation of religion and development. In Clarke G and Jennings M (eds). Development, Civil Society and Faith-Based Organisations: Bridging the Sacred and the Secular. Palgrave Macmillan: Basingstoke and New York: 46-71. DOI: https://doi.org/10.1057/9780230371262_3

Rakodi C. 2012. A framework for analysing the links between religion and development. Development in Practice 22(5-6): 634-650. https://doi.org/10.1080/09614524.2012.685873

Seemann A-K. 2016. Religious work environment - benefit or challenge? A qualitative study on motivation at work in a religiously affiliated hospital. Journal of Hospital Administration 5(5): $106-114$.

Swart I. 2006. Churches as a stock of social capital for promoting social development in western cape communities. Journal of Religion in Africa 36(3-4): 346-378. https://doi.org/10.1163/ 157006606778941913

Ter Haar G, Ellis S. 2006. The role of religion in development: towards a new relationship between the European Union and Africa. European Journal of Development Research 18(93): 351-367. https://doi.org/10.1080/09578810600893403 


\section{Jennings et al.}

Thomas S. 2005. The Global Resurgence of Religion and the Transformation of International Relations. Palgrave Macmillan: London and New York.

Tomalin E. 2012. Thinking about faith-based organisations in development: where have we got to and what next? Development in Practice 22(5-6): 689-703. https://doi.org/10.1080/ 09614524.2012.686600

Tomalin E. 2013. Religions and Development. Routledge, London, New York. DOI: https://doi.org/ 10.1177/0040571X14530862r

Tomalin E. 2020. Global aid and faith actors: the case for an actor-orientated approach to the "turn to religion'. International Affairs 96(2): 323-342. https://doi.org/10.1093/ia/iiaa006

Vander Zaag R. 2013. Canadian faith-based development NGOs and CIDA funding. Canadian Journal of Development Studies/Revue Canadienne d'Études du Développement 24(2): 321-347. https://doi.org/10.1080/02255189.2013.792726

Ware V-A, Ware A, Clarke M. 2016. Domains of faith impact: how 'faith' is perceived to shape faith-based international development organisations. Development in Practice 26(3): 321-333. https://doi.org/10.1080/09614524.2016.1149150

World Vision (2013), World Vision's theory of change. World Vision. https://www.wvi.org/sites/ default/files/WV\%20Theory\%20of\%20Change.Summary_0.pdf. Accessed 23 ${ }^{\text {rd }}$ April 2020.

World Vision Mission Statement. https://www.worldvision.org/about-us/mission-statement. Accessed $23^{\text {rd }}$ April 2020a. 